\title{
Decolorization of Textile Dyes by Cyanobacteria
}

\author{
Maria Estela Silva-Stenico, ${ }^{a}$ Felipe D. P. Vieira, ${ }^{a}$ Diego B. Genuário, ${ }^{a}$ \\ Caroline S. P. Silva, ${ }^{a}$ Luiz Alberto B. Moraes ${ }^{b}$ and Marli Fátima Fiore ${ }^{*, a}$ \\ ${ }^{a}$ University of São Paulo, Center for Nuclear Energy in Agriculture, \\ Molecular Ecology of Cyanobacteria Laboratory, 13400-970 Piracicaba-SP, Brazil \\ ${ }^{b}$ University of São Paulo, Synthetic Organic Chemistry Laboratory, \\ 14040-901 Ribeirão Preto-SP, Brazil
}

\begin{abstract}
Cianobactérias estão amplamente distribuídas no ambiente e podem ser uma alternativa eficaz e econômica para a remoção de corantes de efluentes de indústrias têxteis. O presente trabalho investigou o potencial de seis linhagens de cianobactérias de descolorir onze tipos de corantes têxteis. A absorção máxima de cada corante foi verificada usando um espectrofotômetro. Espectrometria de massas foi utilizada na verificação da degradação e possível remoção de corantes pelas cianobactérias. Os resultados mostraram que todas as linhagens avaliadas foram capazes de remover indigo, amarelo palanil, amarelo indantreno, azul indantreno, azul dispersol, vermelho indantreno e vermelho dispersol em mais de 50\%. O isolado brasileiro Phormidium sp. CENA135 foi capaz de descolorir e remover completamente o índigo azul BANN 30. Este estudo confirmou a capacidade das cianobactérias de descolorir e, possivelmente, degradar corantes têxteis estruturalmente diferentes, sugerindo a possibilidade de sua aplicação em estudos de biorremediação.
\end{abstract}

Cyanobacteria are widely distributed in the environment and may be an effective and economic alternative for removing dyes from textile industry effluents. The present work investigated the potential of six cyanobacterial strains in decolorizing eleven types of textile dyes. The maximum absorbance of each dye was verified using a spectrophotometer. Mass spectrometry was used to verify the removal and possible degradation of dyes by the cyanobacteria. The results showed that all of the evaluated cyanobacteria were able to remove indigo, palanil yellow, indanthrene yellow, indanthrene blue, dispersol blue, indanthrene red and dispersol red by more than $50 \%$. The Brazilian isolate Phormidium sp. CENA135 was able to decolorize and completely remove indigo blue BANN 30. This study confirmed the capacity of cyanobacteria to decolorize and possibly to structurally degrade different textile dyes, suggesting the possibility of their application in bioremediation studies.

Keywords: decolorization, indigo, mass spectrometry, cyanobacteria, biodegradation, bioremediation

\section{Introduction}

Cyanobacteria have a wide and varied impact on natural ecosystems and can act causing beneficial or noxious effects to the health of humans and animals. Some of these oxygenic photoautotrophic organisms are important primary producers of combined nitrogen, ${ }^{1}$ some species possess high nutritional value $^{2}$ and some species are of economical importance. ${ }^{3}$ The representatives of this microbial group have large distribution in the natural ecosystems, habiting freshwater, marine and

*e-mail: fiore@cena.usp.br terrestrial environments. Cyanobacteria colonize places of extreme conditions, such as Arctic and Antarctic areas, thermal sources and areas with little or no illumination. ${ }^{4-7}$ The cyanobacterial diversity is attributed to the wide variety of structural and functional aspects of their cellular morphology and to variations in their metabolic strategies. ${ }^{8-10}$ The metabolic diversity of cyanobacteria is reflected in their ability to survive in such a variety of environments and to synthesize different biochemically active substances that can function as enzymatic inhibitors, herbicides, antimycotics, appetite inhibitors, antimalarials and immunosuppressors. ${ }^{11-14}$ Cyanobacteria also possess a great ability to remove heavy 
metals, such as cadmium,,${ }^{15,16}$ manganese,${ }^{16}$ chrome $^{17}$ and nickel, ${ }^{18}$ and compounds, such as phenol, ${ }^{19,20}$ phenanthrene, ${ }^{21}$ naphthalene ${ }^{22}$ and the pesticide lindane, ${ }^{23}$ from the environment.

Textile dyes represent a large group of organic substances that impose undesirable effects on the environment. An emerging ecological concern is the effluents from the textile industry and the dyeing-related processes that were not conveniently treated before they are introduced into the natural environment reaching reservoirs and water stations. ${ }^{24}$ Although cyanobacteria have a vast distribution in the environment, their role in the degradation of recalcitrant dye compositions remains unclear. A few studies have focused on the application of cyanobacteria for removing or degrading textile dyes, ${ }^{25-28}$ but decolorization of commercially used textile dyes by Brazilian cyanobacterial isolates has not been yet reported. Dyes are heavily employed in several industries, primarily textile industries. Without effective treatment, they can draw significant attention from the environmental authorities because they are easily visualized in any polluted spring. However, depending on the dye type and the application, the final stage of the dye can significantly contribute to the release of waste of several chemical substances with variable composition. When the dyes are not conveniently treated, they are more of an emerging ecological concern. The large number of rules and regulations developed along the years to control waste dyes has imposed a great impact on the dye industry and related businesses.

The present study aimed to investigate the potential of Brazilian strains of cyanobacteria isolated from a mangrove soil, a wastewater stabilization pond and also a foreign strain obtained from a culture collection in removing and degrading eleven different textile dyes.

\section{Experimental}

\section{Culture conditions}

Sources, strain numbers and culture media of the microorganisms investigated in this study are listed in Table 1. These strains were cultured in appropriate liquid media, including BG-11, ${ }^{29}$ SWBG- $11^{30}$ and ASN-III,,${ }^{31}$ and maintained at $24 \pm 1{ }^{\circ} \mathrm{C}$ under constant illumination by white fluorescent light $\left(40 \mu \mathrm{mol}\right.$ photon $\left.\mathrm{m}^{-2} \mathrm{~s}^{-1}\right)$.

\section{Morphological evaluation}

Morphological evaluation of the strains isolated from mangrove (Cardoso Island, São Paulo State, Brazil), which were not studied before, was performed using a Zeiss Axioskop 40 optical light microscope (Carl Zeiss, Jena, Germany) equipped with an AxioVisionLE 4.6 digital imaging system (Carl Zeiss, Jena, Germany). The classification system devised by Komárek and Anagnostidis ${ }^{32,33}$ and morphological diacritical traits for genera were considered. In addition, the order names proposed by Hoffmann et al. ${ }^{34}$ are presented.

\section{Phylogenetic analyses}

Total genomic DNA was extracted from cells of cultured Leptolyngbya sp. CENA134, Phormidium sp. CENA135 and Synechococcus sp. CENA136 using a modified CTAB (cetyl-trimethyl-ammonium bromide)-based extraction method adapted for cyanobacteria. ${ }^{35}$ The 16S rRNA gene from the genomic DNA of the strains was amplified by polymerase chain reaction (PCR) using the $27 \mathrm{~F} 1$ and $1494 \mathrm{Rc}$ oligonucleotide primers. ${ }^{36}$ The amplification was performed by a GeneAmp PCR System 2400 (Applied Biosystems, Foster City, CA, USA), in a $25 \mu \mathrm{L}$ reaction containing $10 \mathrm{ng}$ of genomic DNA, $0.2 \mu \mathrm{mol} \mathrm{L}^{-1}$ of each oligonucleotide primer, $200 \mu \mathrm{mol} \mathrm{L} \mathrm{L}^{-1} \mathrm{dNTPs}$ (deoxynucleoside triphosphates), $3.0 \mu \mathrm{mol} \mathrm{L} \mathrm{L}^{-1} \mathrm{MgCl}_{2}, 1 \times$ PCR buffer and $1.5 \mathrm{U}$ platinum Taq DNA polymerase (Invitrogen, Carlsbad, CA, USA). The PCR reaction consisted of an initial denaturation step at $94^{\circ} \mathrm{C}$ for $4 \mathrm{~min}$; followed by 30 cycles of DNA denaturation at $94{ }^{\circ} \mathrm{C}$ for $20 \mathrm{~s}$, primer annealing at $50{ }^{\circ} \mathrm{C}$ for $30 \mathrm{~s}$, and strand extension at $72{ }^{\circ} \mathrm{C}$ for $2 \mathrm{~min}$; and a final extension step at $72{ }^{\circ} \mathrm{C}$ for $7 \mathrm{~min}$. The PCR product was analyzed on $1 \%$ agarose gel stained with ethidium bromide.

The fresh PCR product was cloned using a pGEM ${ }^{\circledR}$-TEasy Vector System kit (Promega, Madison, WI, USA) according to the manufacturer instructions. Escherichia coli DH5 $\alpha$

Table 1. Cyanobacterial strains used in this study

\begin{tabular}{lll}
\hline Order & Cyanobacterial strains & Origin \\
\hline $\begin{array}{l}\text { Synechococcales } \\
\text { Pseudanabaenales }\end{array}$ & Synechococcus sp. CENA136 & Mangrove, Cardoso Island, Cananéia, São Paulo, Brazil \\
& Leptolyngbya sp. CENA103 & Mangrove, Cardoso Island, Cananéia, São Paulo, Brazil \\
& Leptolyngbya sp. CENA104 & Wastewater stabilization pond system, Cajati, São Paulo, Brazil \\
Oscillatoriales & Phormidium sp. CENA135 & Wastewater stabilization pond system, Cajati, São Paulo, Brazil \\
& Phormidium autumnale UTEX1580 & Mangrove, Cardoso Island, Cananéia, São Paulo, Brazil \\
\hline
\end{tabular}


competent cells were used for transformation. Clones were grown for 14 to $16 \mathrm{~h}$, and recombinant plasmids were isolated from white colonies using an alkali extraction procedure. ${ }^{37}$ DNA sequencing was performed using the cloned PCR product and a DYEnamic ET Terminator Cycle Sequencing kit (Amersham Biosciences, Piscataway, NJ, USA). Primers used for the cycle sequencing were the T7 and M13 promoters of the vector and the internal primers 341-357F (5'-CCTACGGGAGGCAGCAG-3'), 357-341R (5'-CTGCTGCCTCCCGTAGG-3'), 685-704F (5'-GTAGSGGTGAAATSCGTAGA-3'), 704-685R (5'-TCTACGSATTTCACCSCTAC-3'), 1099-1114F (5'-GCAACGAGCGCAACCC-3') and 1114-1099R (5'-GGGTTGCGCTCGTTGC-3'). ${ }^{38}$ The cycle sequencing reaction was performed using the GeneAmp PCR System 2400 (Applied Biosystems, Foster City, CA, USA), and the reaction conditions were 25 cycles of the following steps: $20 \mathrm{~s}$ at $95{ }^{\circ} \mathrm{C}, 15 \mathrm{~s}$ at $50{ }^{\circ} \mathrm{C}$ and $1 \mathrm{~min}$ at $60^{\circ} \mathrm{C}$. After the sequencing reaction was completed, residual dye terminators were removed according to the manufacturer instructions. The purified product was then resuspended in HiDi formamide (Applied Biosystems), and the samples were sequenced using an ABI PRISM 3100 Genetic Analyzer (Applied Biosystems). The cloned PCR product was bidirectionally sequenced, and each set of sequencing data was obtained from at least two independent experiments. The sequenced fragments were assembled into one contig using the Phred/Phrap/Consed software program (Philip Green, University of Washington, Seattle, USA), and only bases with a quality higher than 20 were considered. The nucleotide sequences of $16 \mathrm{~S}$ rRNA obtained in this study and related sequences retrieved from GenBank were aligned, refined and used to generate a phylogenetic tree by neighbor-joining (NJ) algorithm, using the MEGA version 3.1 program package. ${ }^{39}$ The NJ stability of the relationships was assessed by bootstrapping ( 1,000 replicates). The accession numbers for the 16S rRNA nucleotide sequence obtained from Leptolyngbya sp. CENA134, Phormidium sp. CENA135 and Synechococcus sp. CENA136 are HQ730083, HQ730084 and HQ730085, respectively.

\section{Dyes}

The textile dyes were supplied by Toyobo do Brasil Ltda. (Americana-SP, Brazil). In total, eleven dyes were used in this study: indigo BANN 30 (in 30\% aqueous solution), palanil yellow 3G, drimarene yellow CL-R, indanthrene yellow 5GF, drimarene red CL-5B, indanthrene red FBB, dispersol red $\mathrm{C}-4 \mathrm{G}$, dispersol blue $\mathrm{C}-2 \mathrm{R}$, drimarene blue CL-R, indanthrene blue RCL and the polymeric dye remazol brilliant blue R-RBBR (C. I. 61200; reactive blue 19,
Sigma R-8001). The absorbance spectrum of all dyes was determined in the visible range (400 to $900 \mathrm{~nm}$ ) using a Perkin-Elmer spectrophotometer. The dyes were dissolved in BG-11 or SWBG-11 culture media and were scanned.

\section{Enzyme-linked immunosorbent assay (ELISA)}

Microcystin extraction was performed according to Silva-Stenico et al..$^{40}$ Briefly, $2 \mathrm{~mL}$ of the cyanobacterial culture were centrifuged for $10 \mathrm{~min}$ at $10,000 \times \mathrm{g}$, and the supernatant was discarded. The cells were washed with distilled water and were centrifuged. This procedure was performed twice, after which the cells were mixed with $2 \mathrm{~mL}$ of distilled water, microwaved for $1 \mathrm{~min}$, and then centrifuged for $15 \mathrm{~min}$ at $10,000 \times \mathrm{g}$. The supernatant was collected and analyzed using an ELISA assay along with microplate kits for microcystins (Beacon Analytical Systems Inc., Portland, ME, USA) following the manufacturer recommendations, with at least three replicates. The limit of detection of this method is $0.1 \mu \mathrm{g} \mathrm{L}-1$.

\section{Decolorization experiments}

Cyanobacterial inoculum was obtained from a $50 \mathrm{~mL}$ culture after 15 days of growth. Glass tubes containing $10 \mathrm{~mL}$ of corresponding cyanobacterial liquid medium and $0.02 \%$ of different dyes were inoculated with the respective cyanobacteria. Inoculated and control tubes (culture medium + dye, without inoculum) were incubated in continuous luminosity $\left(40 \mu \mathrm{mol}\right.$ photons $\left.\mathrm{m}^{-2} \mathrm{~s}^{-1}\right)$ at $23{ }^{\circ} \mathrm{C}$ under static conditions for 26 days. The same experiment was conducted using solid culture medium (with the addition of $1.8 \mathrm{~g} \mathrm{~mL}^{-1}$ of agar) supplemented with $0.02 \%$ of different dyes. To investigate the decolorization and degradation of dyes, an aliquot $(1 \mathrm{~mL})$ of the culture medium was withdrawn at different time intervals (1, 7 and 26 days). Aliquots were centrifuged at 3,000 $\times \mathrm{g}$ for $15 \mathrm{~min}$ to separate cells. The supernatant was used to assess decolorization by measuring the change in the absorbance of culture supernatants at the maximum absorption wavelength of the respective dyes. Abiotic controls (without microorganism) were included in the entire course of the experiments. Dye decolorization was photometrically measured at visible wavelengths (Table 2) using a Perkin-Elmer scanning spectrophotometer. Each assay was performed in triplicate. Data analysis was performed using Microsoft Excel.

Indigo test

Initially, $300 \mathrm{~mL}$ of BG-11 culture liquid medium supplemented with $0.02 \%$ of indigo were prepared. 
Table 2. Maximum wavelength of each dye used in this study

\begin{tabular}{lcc}
\hline \multirow{2}{*}{ Dye $^{\mathrm{a}}$} & \multicolumn{2}{c}{ UV scanning / nm } \\
\cline { 2 - 3 } Remazol & SWBG-11 & BG-11 \\
Indigo & 595 & 595 \\
Indanthrene blue & 708 & 698 \\
Drimaren blue & 600 & 600 \\
Dispersol blue & 600 & 600 \\
Drimaren red & 600 & 600 \\
Dispersol red & 550 & 550 \\
Indanthrene red & 549 & 515 \\
Drimaren yellow & 514 & 523 \\
Palanil yellow & 430 & 462 \\
Indanthrene yellow & 477 & 477 \\
\hline
\end{tabular}

${ }^{a}$ Chemical structures are presented in Table S1 in the Supplementary Information (SI) section.

Filamentous Phormidium autumnale UTEX1580 were inoculated and grew in this solution. The flasks were incubated at $25^{\circ} \mathrm{C}$ and $130 \mathrm{rpm}$. Samples were collected at 5 , $8,12,14,16,19$ and 26 days of culture. Decolorization was analyzed by determining the absorbance at $698 \mathrm{~nm}$ and was expressed as relative percentage, taking the non-inoculated control as $100 \%$. The experiments were performed in duplicate. Non-inoculated culture medium was used as a control.

\section{Remazol brilliant blue R (RBBR) test}

Two $250 \mathrm{~mL}$ flasks containing $100 \mathrm{~mL}$ of BG-11 culture medium were inoculated as follows: (A) P. autumnale UTEX1580 + RBBR (0.05\%) and (B) RBBR (0.02\%) were added to individual flasks containing $P$. autumnale UTEX1580 after 15 days of growth. The two flasks were incubated at $25^{\circ} \mathrm{C}$ and $130 \mathrm{rpm}$ under constant illumination (40 $\mu \mathrm{mol}$ photons $\left.\mathrm{m}^{-2} \mathrm{~s}^{-1}\right)$.

Another test was performed using solid BG-11 culture medium to verify the maximum capacity of the strain to decolorize higher concentrations of the dye. The concentrations of RBBR used in this experiment were $0.005,0.01,0.02$ and $0.04 \%$.

\section{Mass spectrometry}

The samples were subjected to LC-MS (liquid chromatography-mass spectrometry) study and analysis of the compounds were achieved using an Agilent 6410 Triple Quadrupole LC-MS equipped with Agilent 1200 Series Binary Pump SL pumping system and Agilent 1200 Autosampler (Agilent Technologies Inc. Santa Clara, CA,
USA). Data acquisition and analysis were performed using Agilent MassHunterWorkstation software. The electrospray ionization (ESI) source was employed in positive mode, and the source parameters for the MS detection were set as follows: drying gas was nitrogen heated at $300^{\circ} \mathrm{C}$, capillary voltage was held at $3 \mathrm{kV}$. The MS/MS parameters were set as follows: dwell time was $200 \mathrm{~ms}$, fragmentor voltage was set at $200 \mathrm{~V}$, collision gas was nitrogen and collision energy was set at $30 \mathrm{eV}$. The MS system was operated in full scan and multiple reaction modes (MRM). The mobile phase A consisted of ultrapure water (Milli-Q) and mobile phase B consisted of methanol, both containing $0.1 \%$ $(\mathrm{v} / \mathrm{v})$ of formic acid. The flow rate was $0.3 \mathrm{~mL} \mathrm{~min}^{-1}$. The MS optimization was performed via direct infusion of the cyanobacterial culture supernatant mixed with $0.5 \mathrm{~mL}$ of methanol:formic acid $0.1 \%(50: 50 \mathrm{v} / \mathrm{v})$ into the ESI source of the mass spectrometer. Molecular ions were scanned in the range of 100 to $200 \mathrm{Da}$. The identification of fragments was aided by comparison to fragment patterns according to NIST library. ${ }^{41}$

\section{Results and Discussion}

The three cyanobacteria (CENA134, CENA135 and CENA136) isolated from Brazilian mangrove used in this study were morphologically and molecularly characterized showing their position in the cyanobacterial classification system. According to the cyanobacterial classification systems, the strains CENA134, CENA135 and CENA136 belong to the genera Leptolyngbya, Phormidium and Synechococcus, respectively. Filamentous non-heterocystous forms of Leptolyngbya and Phormidium genera are included in Pseudanabaenales and Oscillatoriales (order), respectively, whereas the unicellular form Synechococcus is inserted to Synechococcales (order) ${ }^{34}$ Main morphological features of Leptolyngbya genus are thin, long, isopolar and immotile filaments with facultative sheaths and cells longer than wide without aerotopes. ${ }^{42}$ Phormidium genus is characterized by the motility of the unbranched and isopolar filaments and cells wider than long. ${ }^{42}$ In contrast, the coccoid form Synechococcus possesses oval or cylindrical cells grouped in irregular cluster, not forming colonies or remaining solitary ${ }^{42}$ (Figure S1 in the Suplemmentary Information (SI) section). The other cyanobacterial strains used in this study were previously classified. ${ }^{43,44}$

Nearly complete nucleotide sequences $(1,417,1,414$ and $1,409 \mathrm{bp}$ ) of the $16 \mathrm{SrRNA}$ gene were amplified and sequenced from mangrove strains Leptolyngbya sp. CENA134, Phormidium sp. CENA135 and Synechococcus sp. CENA136, respectively. Phylogenetic relationships of the $16 \mathrm{~S}$ rRNA gene sequences from the studied strains were 
compared to other cyanobacterial sequences retrieved from GenBank (Figure 1). Unicellular and filamentous non-heterocystous forms were dispersed within the tree. Synechococcus sp. CENA136 was clustered in a major clade containing only sequences from Synechococcus genus, with a high bootstrap value (100\%). Leptolyngbya genus formed two distinct clusters. The first group containing the sequence of Leptolyngbya sp. CENA134 isolated from mangrove is affiliated to unicellular forms (Synechococcus sp.), with a bootstrap value of $91 \%$. This sequence (Leptolyngbya sp. CENA134) is loosely related to the Antarctic isolate Leptolyngbya antarctica ANT.ACEV6. $1^{45}$ and other Leptolyngbya isolates from Bubano Basin, Imola, Italy (Leptolyngbya sp. 0BB24S04 and Leptolyngbya sp. 0BB32S02). ${ }^{46}$ The second cluster assembled the Leptolyngbya sp. CENA104 sequence in a well-supported clade containing sequences from the type species of Leptolyngbya (Leptolyngbya boryana and Leptolyngbya foveolarum). In contrast, the Leptolyngbya sp. CENA103 sequence is distantly related to this cluster, with a bootstrap value of $64 \%$. These groups seem to be most related to oscillatorian members of Phormidium genus. However, previous studies have shown that strains were assigned to the genus Leptolyngbya cluster with other members of filamentous non-heterocystous cyanobacteria. ${ }^{47,48}$ Phormidium sp. CENA135 and Phormidium autumnale UTEX1580 sequences clustered in a group exclusively containing other Phormidium sequences, although the sequence obtained from the mangrove strain appears loosely related to the sequence of Phormidium pseudopristleyi ANT. ACEV5.3 isolated form Antarctic in an internal branch. Morphological analyses of the mangrove strains are in agreement with molecular results.

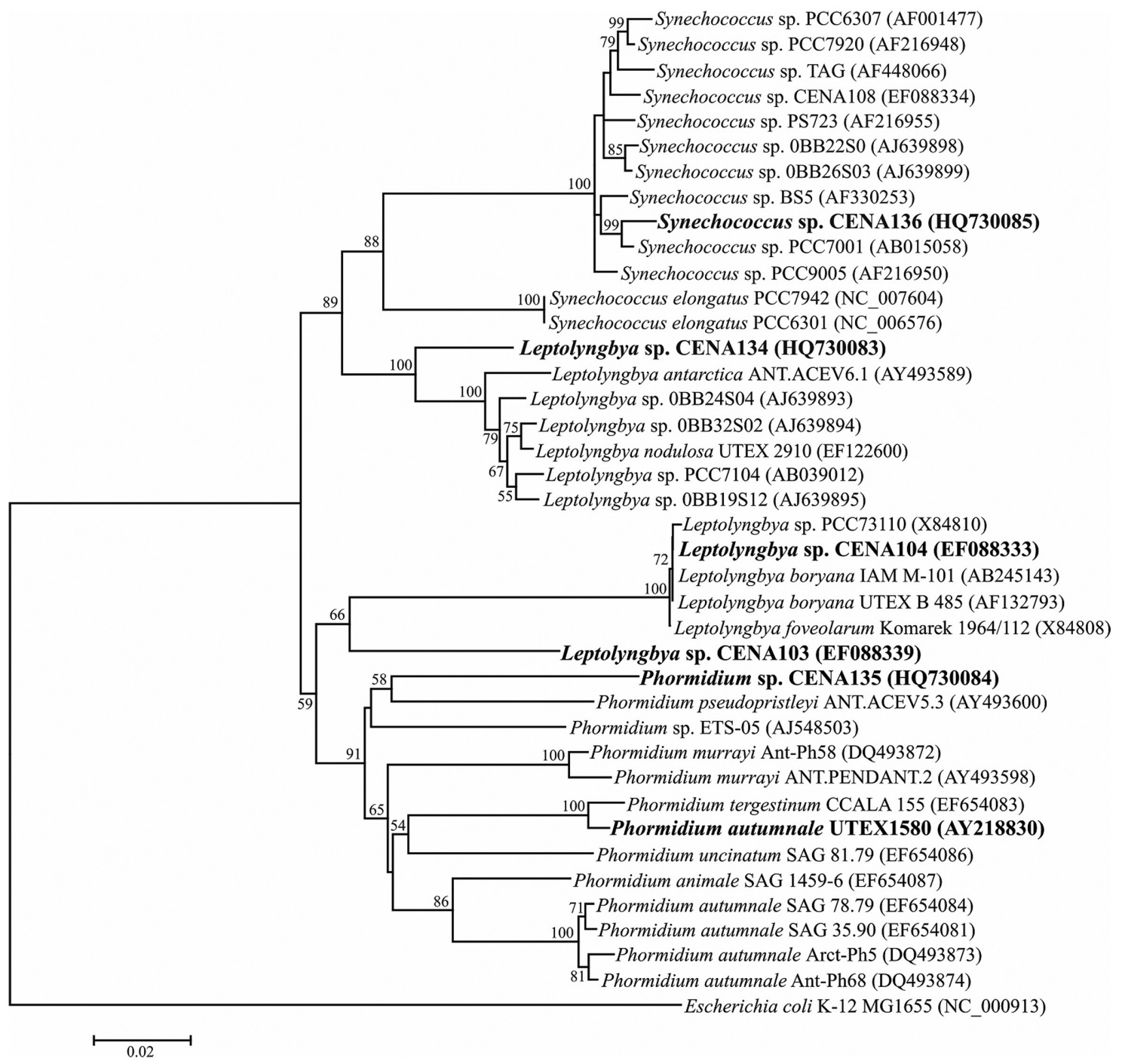

Figure 1. Phylogenetic tree based on 16S rRNA sequences. The studied cyanobacterial strains are shown in bold. Leptolyngbya sp. CENA134, Phormidium sp. CENA135 and Synechococcus sp. CENA136 sequences were obtained in this study. Numbers near nodes indicate bootstrap values over $50 \%$ for NJ analysis. 
The capability to decolorize eleven textile dyes was evaluated in six strains of cyanobacteria. To analyze the decolorization of each dye, a scanning was performed using a UV detector in the range of 400 to $900 \mathrm{~nm}$. The values of the maximum absorbance of each dye and the wavelength used to verify the decolorization by the cyanobacteria are presented in Table 2. All the six cyanobacterial strains did not release pigments that could interfere with the decolorization analysis. Solid cultures are shown in Figure S2 (SI section), and the removal of the dye can be visualized. Microcystin analysis was performed to verify whether they were microcystin-producing strains. In the case of a positive identification, the strain would not be chosen for further analysis because hepatotoxin could be released to the environment. All cell extracts elicited negative immunoreaction for microcystins in the ELISA test. Therefore, all of the strains were selected for dye decolorization analysis.

It was verified $15 \%$ of decolorization at the $7^{\text {th }}$ day of growth for some strains (data not shown). Figure 2 shows the results of the percentage of dye decolorization at the end of $26^{\text {th }}$ day of cyanobacterial growth. Leptolyngbya $\mathrm{sp}$. CENA103 discolored 3 dyes: indigo (86\%), palanil yellow (83\%) and indanthrene yellow (68\%). Leptolyngbya sp. CENA104 was able to discolor the dyes indigo (68\%) and palanil yellow (78\%). P. autumnale UTEX1580 removed 6 dyes: indigo (88\%), indanthrene blue (60\%), dispersol blue $(65 \%)$, indanthrene red (88\%), palanil yellow (62\%) and indanthrene yellow (79\%). Leptolyngbya sp. CENA134 removed 3 dyes: indigo (63\%); palanil yellow (77\%) and indanthrene yellow (58\%). Phormidium sp. CENA135 was able to remove 3 dyes: indigo (100\%), palanil yellow $(51 \%)$ and indanthrene yellow (70\%). Synechococcus sp. CENA136 discolored dispersol red (54\%).
Although the results obtained from the Synechococcus sp. CENA136 were relatively good, the absorbance readings were not accurate because when the suspended cells of this unicellular cyanobacterium in culture medium were centrifuged, the dyes also precipitated with the cells, causing the decrease in absorbance values. In the culture media showing the decolorization greater than $50 \%$, it was not possible to observe differences in the coloration, as shown in Figure S3 (SI section).

To verify if the total decolorization of indigo BANN 30 by Phormidium sp. CENA135 was not influenced by light, a solution of SWBG-11 liquid medium containing the dye was prepared and exposed to the light in the same period that the experiment with this cyanobacterium was conducted. Figure S3 M (SI section) displays the result of the experiment showing no photodecolorization.

The removal of RBBR by the cyanobacteria P. autumnale UTEX1580, Leptolyngbya sp. CENA103 and Leptolyngbya sp. CENA104 was not expressive. In the case of the indigo dye, it was possible to achieve the removal of $100 \%$ by Phormidium sp. CENA135. The indanthrene blue was not efficiently discolored by Leptolyngbya $\mathrm{sp}$. CENA103 or Leptolyngbya sp. CENA104. Drimarene blue, red and yellow were not removed by any of the tested cyanobacteria, except for Leptolyngbya sp. CENA104, which removed $34 \%$ of drimarene red. P. autumnale UTEX1580 only removed dispersol blue and indanthrene red by more than $50 \%$. The remotion of palanil yellow was also more than $50 \%$ by almost all of the cyanobacteria. Indanthrene yellow was removed by more than $50 \%$ by $P$. autumnale UTEX1580, Leptolyngbya sp. CENA103, Leptolyngbya sp. CENA134 and Phormidium sp. CENA135.

In the indigo $(0.02 \%)$ test experiment with $P$. autumnale UTEX1580, decolorization of $70 \%$ was obtained after

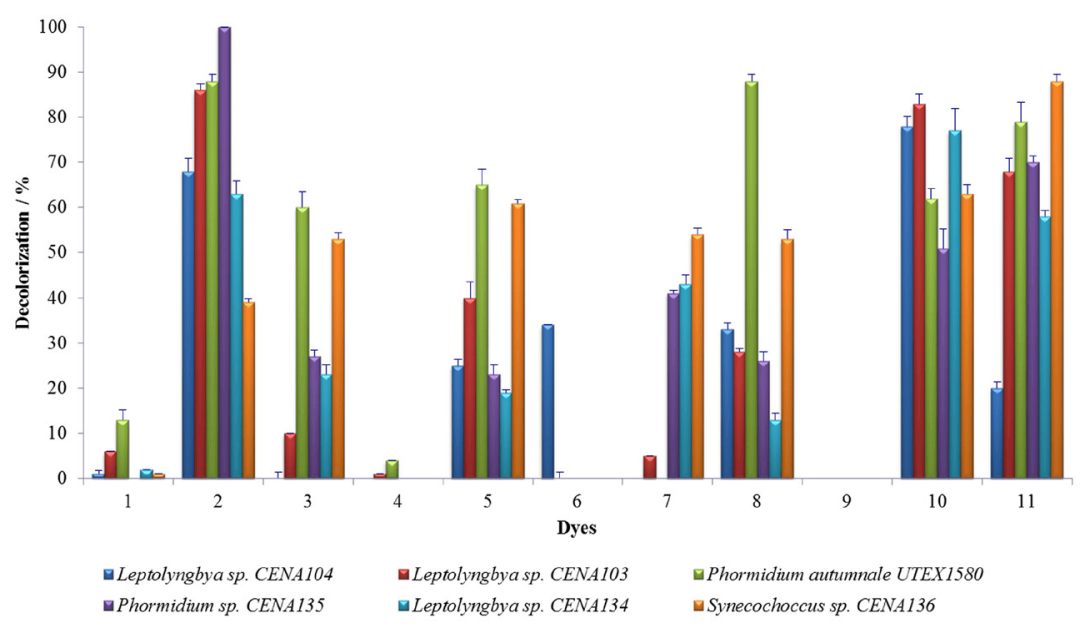

Figure 2. Decolorization of different dyes by cyanobacteria in liquid medium after 26 days of growth: (1) remazol, (2) indigo, (3) indanthrene blue, (4) drimaren blue, (5) dispersol blue, (6) drimaren red, (7) dispersol red, (8) indanthrene red, (9) drimaren yellow, (10) palanil yellow and (11) indanthrene yellow. Where error bars are not shown, the standard error of triplicates is smaller than the size of the symbol. 
26 days of growth (Figure 3). However, in the presence of RBBR at concentration of $0.02 \%$, the P. autumnale UTEX1580 grew but was not able to degrade or discolor the dye, despite increase in its biomass. Furthermore, at the concentration of $0.05 \%$ RBBR completely inhibited the growth of $P$. autumnale UTEX1580 (data not shown). The growth of $P$. autumnale UTEX1580 in the BG-11 solid culture medium with different dye concentrations was similar to that in the liquid medium and it was observed that with dye concentrations lower than $0.02 \%$, the cyanobacterium was able to grow, whereas at the concentration of $0.04 \%$, the growth was inhibited.

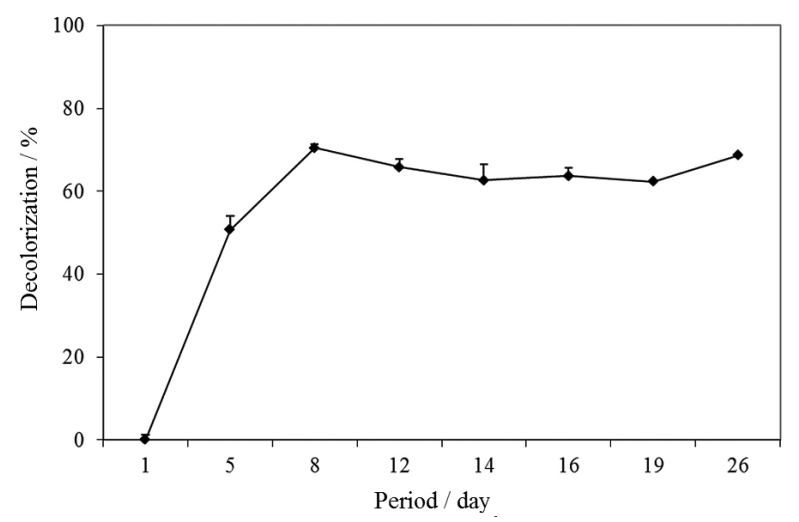

Figure 3. Percentage of indigo decolorization by P. autumnale UTEX1580 during 26 days of growth.

Few other studies conducted abroad showed the capability of cyanobacteria to decolorize textile dyes. Jinqi and Houtian ${ }^{25}$ found that Oscillatoria tenuis can degrade aniline. Shah et al. ${ }^{26}$ reported that the marine cyanobacterium Phormidium valderianum is able to remove more than $90 \%$ of the textile dyes acid red, acid red 119 and direct black 155. A study conducted by Parikh and Madamwar ${ }^{27}$ screened cyanobacteria isolated from polluted industrial textile effluents for their ability to decolorize cyclic azo dyes. Gloeocapsa pleurocapsoides and Phormidium ceylanicum decolorized acid red 97 and FF sky blue dyes by more than $80 \%$ after 26 days. In the same study, the cyanobacterium Chroococcus minutus was the only strain which decolorized 55\% of amido black 10B. In another study, the bioaccumulation of reactive dyes by thermophilic cyanobacteria was reported. ${ }^{28}$ They used three different dyes: reactive red $\mathrm{RB}$, remazol blue and reactive black $\mathrm{B}$ and two cyanobacterial strains: Synechococcus sp. and Phormidium sp. with maximum uptake yields ranging from 13 to $97 \%$ at all tested dye concentrations.

The textile dye indigo is well documented in the literature. Therefore, the use of enzymes to oxidize indigo yielding isatin (indole-2,3-dione), which is further decomposed to anthranilic acid (2-aminobenzoic acid) is already established. In order to detect degradation products by cyanobacterial strains, mass spectrometry was used to monitor the formation of isatin $(\mathrm{m} / \mathrm{z}, 149)$ and anthranilic acid $(\mathrm{m} / \mathrm{z}$ 139), two major constituents of the metabolic pathway of indigo $(\mathrm{m} / \mathrm{z}, 263)$ (Figure S4 in the SI section). These products were visualized in all the extracts after five days of inoculation. An example is showed in Figures S5 and S6 (SI section). After the $10^{\text {th }}$ day of growth, indigo and anthranilic acid were degraded by all cyanobacterial strains, with the exception of Synechococcus sp. CENA136. The results suggest that a degradation pathway of indigo was activated during cyanobacterial growth.

\section{Conclusions}

This study showed that all cyanobacteria evaluated were able to decolorize $50 \%$ of at least one dye. One Brazilian strain (Phormidium sp. CENA135) decolorized $100 \%$ and completely removed the dye indigo BANN 30. Furthermore, cyanobacteria not originated from textile effluents, but from other Brazilian environments showed capability of decolorize commercially used textile dyes. Therefore, efficient color removal organisms can be searched in all type of environment and not only in a particular one. The research of cyanobacteria to remove color in dye wastewaters is still in the early stage, but is a promising alternative of biological treatment. Our results showed that the cyanobacteria evaluated can decolorize and degrade dyes and that they may also be used in other studies, such as bioremediation.

\section{Acknowledgements}

This study was supported by grants from the State of São Paulo Research Foundation (FAPESP 2009/05474-5) and Brazilian National Research Council (CNPq 559720/2009-2). M. F. Fiore would like to thank CNPq for a research fellowship (308299/2009-4). M. E. Silva-Stenico was the recipient of post-doctoral fellowship from FAPESP (2010/09867-9) and CNPq (151931/2010-0). C. S. P. Silva and D. B. Genuário were supported by graduate fellowship from FAPESP (2006/01671-2 and 2010/00321-3, respectively). We thank Prof. Valdemar Tornisielo for LC-MS analysis support in the Laboratory of Ecotoxicology, CENA-USP, Brazil.

\section{References}

1. Haselkorn, R.; Buikema, W. J. In Biological Nitrogen Fixation; Stacey, G.; Burris, R. H.; Evans, H. J., eds.; Chapman \& Hall: New York; USA, 1992, p. 166. 
2. Dillon, J. C.; Phuc, A. P.; Dubacq, J. P.; World Rev. Nutr. Diet. 1995, 77, 32.

3. Patterson, G. M. L.; J. Sci. Ind. Res. 1996, 55, 669.

4. Castenholz, R. W.; J. Phycol. 1976, 12, 54.

5. Dor, I.; Damin, A.; Arch. Hydrobiol. 1996, 83, 197.

6. Skulberg, A. M. In Hydrogen Energy System. Production and Utilization of Hydrogen and Future Aspects; Yürüm, Y., ed.; NATO ASI Series Kluwer Academic Publishers: Dordrecht, The Netherlands, 1995, p. 95.

7. Whitton, B. A.; Potts, M. In The Ecology of Cyanobacteria. Their Diversity in Time and Space; Volesky, B., ed.; Kluwer Academic Publishers: Dordrecht, The Netherlands, 2000, p. 1.

8. Carr, N. G.; Whitton, B. A.; The Biology of Blue-Green Algae; Blackwell Scientific Publications: Oxford, UK, 1973.

9. Castenholz, R. W.; Waterbury, J. B. In Bergey's Manual of Systematic Bacteriology; Staley J. T.; Bryant, M. P.; Pfenning, N.; Holt, J. G., eds.; Williams \& Wilkins: Baltmore, 1989, p. 1710.

10. Rippka, R.; Methods Enzymol. 1988, 167, 28.

11. Burja, A. M.; Banaigs, B.; Abou-Mansour, E.; Burgess, J. G.; Wright, P. C. Tetrahedron 2001, 57, 9347.

12. Etchegaray, A.; Rabelo, E.; Dieckmann, R.; Moon, D. H.; J. Appl. Phycol. 2004, 16, 237.

13. Moore, R. E.; J. Ind. Microbiol. Biotechnol. 1996, 16, 134.

14. Namikoshi, M.; Rinehart, K. L.; J. Ind. Microbiol. Biotechnol. 1996, 17, 373 .

15. Matsunaga, T.; Takeyama, H.; Nakao, T.; Yamazawa, A.; J. Biotechnol. 1999, 70, 33.

16. Mohamed, Z. A.; Water Res. 2001, 35, 4405.

17. Khattar, J. I. S.; Sarma, T. A.; Singh, D. P.; Enzyme Microb. Technol. 1999, 25, 564.

18. Asthana, R. K.; Chatterjee, S.; Singh, S. P.; Process Biochem. 1995, 30, 729.

19. Kirkwood, A. E.; Nalewajko, C.; Fulthorpe, R. R.; Can. J. Microbiol. 2005, 51, 531.

20. Wurster, M.; Mundt, S.; Hammer, E.; Schauer, F.; Lindequist, U.; J. Appl. Phycol. 2003, 15, 171.

21. Narro, M. L.; Cerniglia, C. E.; Van Baalen, C.; Gibson, D. T.; Appl. Environ. Microbiol. 1992, 58, 1351.

22. Narro, M. L.; Cerniglia, C. E.; Vanbaalen, C., Gibson, D. T.; Appl. Environ. Microbiol. 1992, 58, 1360.

23. Kuritz, T.; Wolk, C. P.; Appl. Environ. Microbiol. 1995, 61, 234.

24. Guaratini, C. C. I.; Zanoni, M. V. B.; Quím. Nova 2000, 23, 71.

25. Jinqi, L.; Houtian, L.; Environ. Pollut. 1992, 75, 273.

26. Shah, V.; Garg, N.; Madamwar, D.; World J. Microbiol. Biotechnol. 2001, 17, 499.

27. Parikh, A.; Madamwar, D.; Biotechnol. Letter 2005, 27, 323.

28. Sadettin, S.; Donmez, G.; Process Biochem. 2006, 41, 836.
29. Allen, M. B.; J. Phycol. 1968, 4, 1.

30. Castenholz, R. W.; Methods Enzymol. 1988, 67, 68.

31. Rippka, R.; Deruelles, J.; Waterbury, J. B.; Stanier, R. Y.; J. Gen. Microbiol. 1979, 111, 1.

32. Komárek, J.; Anagnostidis, K.; Cyanoprokaryota, Part 1: Chroococcales, Susswasserflora von Mitteleuropa, Bd 19/1; Gustav Fischer Verlag: Stuttgart, Germany, 1999.

33. Komárek, J.; Anagnostidis, K.; Cyanoprokaryota, Part 2: Oscillatoriales, Susswasserflora von Mitteleuropa, Bd 19/2; Spektrum Akademischer Verlag: Heidelberg, Germany, 2005.

34. Hoffmann, L.; Komárek, J.; Kaštovcký, J.; Algol. Stud. 2005, $117,95$.

35. Fiore, M. F.; Moon, D. H.; Tsai, S. M.; Lee, H.; Trevors, J. T.; J. Microbiol. Methods 2000, 39, 159.

36. Neilan, B.A.; Jacobs, D.; Del Dot, T.; Blackall, L. L.; Hawkins, P. R.; Cox, P. T.; Goodman, A. E.; Int. J. Syst. Bacteriol. 1997, 47, 693.

37. Birnboim, H. C.; Doly, J.; Nucleic Acids Res. 1979, 7, 1513.

38. Lane, D. J. In Nucleic Acid Techniques in Bacterial Systematics; Stackebrandt, E.; Goodfellow, M., eds.; Wiley: Chichester, UK, 1991, p. 115.

39. Kumar, S.; Tamura, K.; Nei, M.; Briefings Bioinf. 2004, 5, 150.

40. Silva-Stenico, M. E.; Cantúsio Neto, R.; Alves, I. R.; Moraes, L. A. B.; Shishido, T. K.; Fiore, M. F.; J. Braz. Chem. Soc. 2009, 20, 535.

41. http://webbook.nist.gov/chemistry/name-ser.html accessed on October, 2012

42. www.cyanodb.cz accessed on September, 2012.

43. Furtado, A. L. F. F.; Calijuri, M. C.; Lorenzi, A. S.; Honda, R. Y.; Genuário, D. B.; Fiore, M. F.; Hydrobiologia 2009, 627, 195.

44. Fiore, M. F.; Neilan, B. A.; Copp, J. N.; Rodrigues, J. L. M.; Tsai, S. M.; Lee, H.; Trevors, J. T.; Water Res. 2005, 39, 5017.

45. Taton, A.; Grubisic, S.; Ertz, D.; Hodgson, D. A.; Picardi, R.; Biondi, N.; Tredici, M.; Mainini, M.; Losi, D.; Marinelli, F.; Wilmote, A.; J. Phycol. 2006, 42, 1257.

46. Castiglioni, B.; Rizzi, E.; Frosini, A.; Sivonen, K.; Rajaniemi, P.; Rantala,A.; Mugnai, M.A.; Ventura, S.; Wilmotte, A.; Boutte, C.; Grubisic, S.; Balthasart, P.; Consolandi, C.; Bordoni, R.; Mezzelani, A.; Battaglia, C.; De Bellis, G.; Appl. Environ. Microbiol. 2004, 70, 7161.

47. Litvaitis, M. K.; Hydrobiologia 2002, 468, 135.

48. Marquardt, J.; Palinska, K. A.; Arch. Microbiol. 2006, 187, 397.

Submitted: June 16, 2012

Published online: October 16, 2012

FAPESP has sponsored the publication of this article. 